\title{
Spatial structure of coral reef fish communities in the Ryukyu Islands, southern Japan
}

\section{Répartition spatiale des communautés de poissons dans différentes îles coralliennes des Ryukyus (sud du Japon)}

\author{
David Lecchini $^{\text {a,*, }}{ }^{\text {Mehdi Adjeroud }}{ }^{\text {a,b }}$, Morgan S. Pratchett ${ }^{\text {a,c }}$, Laurence Cadoret ${ }^{\text {a,b }}$, \\ René Galzin ${ }^{\text {a }}$ \\ ${ }^{a}$ École pratique des Hautes-Études, UMR CNRS 8046, Université de Perpignan, 66860 Perpignan, France \\ ${ }^{b}$ Department of Chemistry, Biology, and Marine Science, University of the Ryukyus Nishihava, Okinawa 903-01, Japan \\ c Centre for Coral Reef Biodiversity, James Cook University, Townsville, Qld 4811, Australia
}

\begin{abstract}
Coral reef fishes often exhibit a high degree of structure in their distribution and abundance, but the factors that influence their spatial arrangement are poorly understood. This study sought to explain the spatial structure of coral reef fish communities in the Ryukyu Archipelago, southern Japan. Visual surveys of coral reef fishes were conducted at multiple stations across the fringing reef (from the inner reef flat to the outer slope) at each of three different islands; Aka, Ishigaki and Sesoko. Spatial variation in fish communities (within and among reefs) was then compared to changes in environmental variables (water depth, distance from the shoreline, reef zone, coral abundance and coral richness). Despite being small islands, the total species richness of coral reef fishes in the Ryukyu Islands was very high ( $>87$ species per reef). Mean abundance of reef fishes was also very high $\left(x=2.26 \pm 0.20\right.$ S.E. fishes per $\left.\mathrm{m}^{2}\right)$, but more than $80 \%$ of all fishes were from the family Pomacentridae. The structure of fish communities was very consistent among reefs, but varied greatly among zones within each reef. On the reef flat, the fish community was dominated by the pomacentrid Chrysiptera cyanea and the acanthurid Acanthurus nigrofuscus. In contrast, the reef slope community was characterised by high densities of the pomacentrids Pomacentrus lepidogenys and P. richardsoni, as well as high densities of the acanthurid Ctenochaetus striatus. Canonical correspondence analysis showed that the structure of the coral reef fish communities varied in relation to reef zone, water depth, and distance from the shoreline, but these changes were not related to spatial variation in either coral abundance or coral richness.
\end{abstract}

(C) 2003 Éditions scientifiques et médicales Elsevier SAS and Ifremer/CNRS/IRD. All rights reserved.

\section{Résumé}

Les poissons des récifs coralliens ont souvent une forte structuration spatio-temporelle de leur distribution et de leur abondance, mais les facteurs qui l'influencent sont encore peu connus. Cette étude a pour but d'analyser la distribution spatiale des communautés de poissons coralliens dans l'archipel des Ryukyus (sud du Japon). Des comptages visuels de poissons sont réalisés sur trois îles coralliennes (Aka, Ishigaki et Sesoko) avec différentes stations d'échantillonnage réparties du récif frangeant à la pente externe. La distribution spatiale obtenue à l'échelle intra- et inter-îles, est ensuite corrélée à différents facteurs environnementaux (profondeur de chaque station, distance des stations à la côte, unité géomorphologique sur laquelle la station est présente - lagon ou pente externe, abondance et richesse spécifique des coraux). Malgré le fait d'être des îles de petites tailles, la richesse spécifique des poissons aux Ryukyus est très élevée ( $>87$ espèces par île). L'abondance moyenne des poissons est aussi trés forte $\left(x=2,26 \pm 0,20 \mathrm{ES}\right.$ poissons par $\left.\mathrm{m}^{2}\right)$, mais plus de $80 \%$ de cette abondance provient de la famille des Pomacentridae. Enfin, la structure des communautés des poissons est identique entre les îles, mais varie fortement à l'échelle insulaire avec la différenciation de deux communautés, une lagonaire et une de la pente externe. La communauté lagonaire est dominée par le Pomacentridae Chrysiptera cyanea et l'Acanthuridae Acanthurus nigrofuscus alors que la communauté de la pente externe est caractérisée par une forte densité de Pomacentridae, Pomacentrus lepidogenys et P. richardsoni, et d'Acanthuridae, Ctenochaetus striatus. L'analyse des correspondances canoniques démontre que la différenciation des deux communautés est corrélée à la localisation géomorphologique, à la profondeur et à la distance à la côte des stations, et non à l'abondance et à la richesse spécifique des coraux.

(C) 2003 Éditions scientifiques et médicales Elsevier SAS and Ifremer/CNRS/IRD. All rights reserved.

\footnotetext{
* Corresponding author.

E-mail address: lecchini@univ-perp.fr (D. Lecchini).
} 
Keywords: Canonical correspondence analysis; Distribution; Pomacentridae; Zonation

Mots clés : Analyse des correspondances canoniques ; Répartition spatiale ; Pomacentridae ; Zonation

\section{Introduction}

A major goal of ecology is to explain spatial patterns in the distribution of organisms and the corresponding spatial structure of communities. For coral reef fishes, potential factors that influence species distributions are many and varied (see reviews by Caley et al., 1996; Lecchini and Galzin, in press). These factors can be broadly categorised as biological (e.g. recruitment, competition, predation), physical (e.g. temperature, salinity) or historical (disturbance events). Previous studies have focussed almost entirely on biological factors, relating the distribution of coral reef fishes to patterns of recruitment (Caselle, 1999; Shima, 1999), competition (Levin, 1993; Booth, 1995), predation (Booth, 2002; Steele and Forrester, 2002), and/or the availability of resources (Hindell et al., 2002; Holbrook et al., 2002). In many instances, biological factors have been shown to explain a large proportion of variability in the distribution of coral reef fishes (Holbrook et al., 2002). Conversely, there are many studies that have found that the distribution and abundance of adult populations cannot be explained exclusively by biological factors (Bell et al., 1985). Conflicts regarding the importance of biological factors such as recruitment, predation or resource requirements in structuring fish populations and communities may result from differences in sampling and scale between studies (Bell et al., 1985; Syms and Jones, 2000), or from real differences in the recruitment history and demographic parameters of different fish species (Jones, 1991). At the most fundamental level, biological factors must have an influence on the distribution of coral reef fishes (e.g. no animal can live where there is no suitable prey), but further work is required to assess the generality of their influence on different fish species, at different scales, and also within the context of physical and historical factors.

On tropical coral reefs, as in temperate marine environments, fishes are distributed neither uniformly nor at random, but often exhibit striking patterns in their distribution and abundance (Galzin, 1987; Letourneur, 1992; Cadoret et al., 1995). These patterns are most apparent along physical gradients, such as from near shore to oceanic waters (Williams, 1982; Green et al., 1987; Adjeroud et al., 1998), suggesting that physical processes might exert considerable influence on the distribution of fishes. Recent research showing interspecific variation in the physiological capabilities of coral reef fishes (Bellwood and Wainwright, 2001; Fulton et al., 2001) provides both a mechanism, and presents clear evidence showing the influence of physical factors on spatial distributions of reef fish species. Studies of the relationships between physical factors (e.g. water flow, wave exposure and water depth) and patterns in the distribution and abundance of coral reef fishes may, therefore, provide interesting in- sights into the role of physical processes in structuring fish communities. However, physical factors often occur as interrelated gradients (Denny, 1988), and may also be accompanied by corresponding changes in habitat structure (e.g. coral cover), making it difficult to discern the independent influence of any single physical factor (Rakocinski et al., 1992; McGehee, 1994). It is, therefore, necessary to undertake multi-factorial studies, and apply appropriate analyses, that can elucidate the relative contribution of several different factors in determining the distribution of coral reef fishes.

The aims of this study were: (i) to investigate the spatial structure of fish communities on coral reefs in the Ryukyu Archipelago, southern Japan, and (ii) to relate spatial patterns in the structure of the fish communities to gradients in environmental variables. This study represents the most detailed study to date of coral reef fish communities in the Ryukyu Archipelago, representing the northernmost populations of coral reef fishes anywhere in the world. It is, therefore, interesting to assess whether the structure of these fish communities conforms to the observed structure of fish communities in other coral reef systems. Moreover, this study provides important baseline data that will enable subsequent investigation of temporal changes in fish communities, as coral reefs in the Ryukyu Archipelago are subject to considerable pressure from anthropogenic impacts (Nishihira, 1987) and natural disturbances (Sano, 2001).

\section{Materials and methods}

This study was conducted in August 1995, in the Ryukyu Archipelago $\left(24-30^{\circ} \mathrm{N}\right)$, southern Japan. Sampling was carried out at three different islands (Aka, Ishigaki and Sesoko), separated by $100-500 \mathrm{~km}$ along an arc of islands extending between Kyushu and Taiwan (Fig. 1). At each island, a single study location was selected (labelled 'Aka', 'Ish' and 'Ses' according to the respective Islands) (Fig. 1). All study locations were located on the north-western side of their respective islands (thereby ensuring similar levels of exposure), and each location had a very similar reef profile with a clearly defined reef flat, reef crest and outer slope. The reef flat (1.5-2 m depth) represented an area of low relief comprised predominantly of carbonate pavement, extending seaward for approximately $100 \mathrm{~m}$ from the shoreline to a slightly raised reef crest. Beyond the reef crest, the outer slope represented the steeply inclined reef front, which extended seaward to a sandy floor (Fig. 2).

In order to document the distribution of fishes across the fringing reef, sampling was conducted at seven different stations extending from near shore to oceanic waters within each location (Fig. 2). Stations 1-4 were placed equidistant across the reef flat, while stations 5, 6 and 7 were located on 

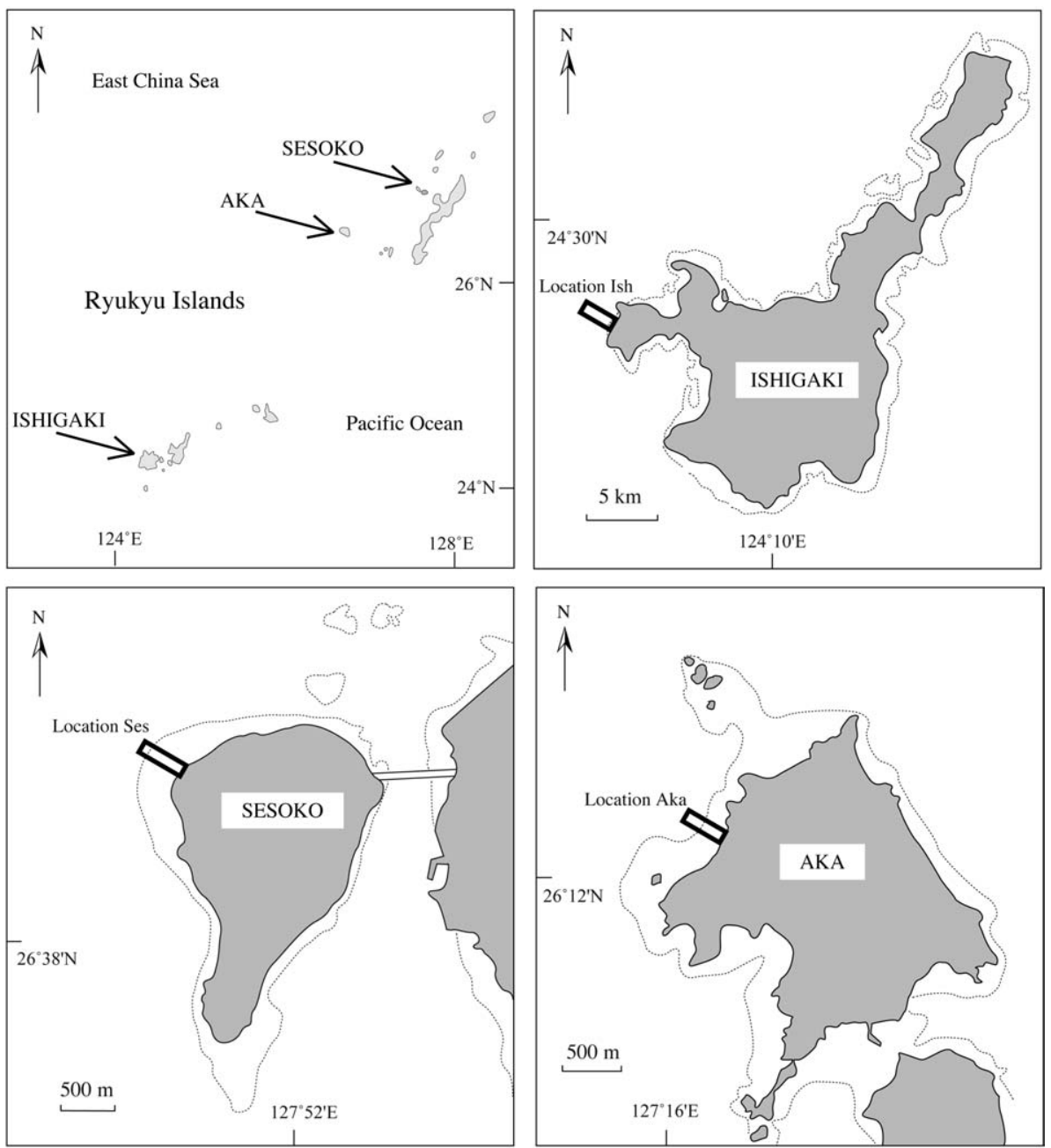

Fig. 1. Map of Ryukyu Islands, southern Japan, showing the three study reefs (Aka, Ishigaki and Sesoko) and respective study locations ('Aka', 'Ish' and 'Ses'). Dashed lines indicate the reef outline.

the reef slope at 5, 10 and $15 \mathrm{~m}$ depth, respectively. The abundance of coral reef fishes was measured on three replicate $30 \times 5 \mathrm{~m}$ belt transects within each station, at every location. All transects were orientated parallel to the reef crest, and run from a haphazardly selected starting point within each station. Fishes were censused during two passes over each transect, following Smith and Tyler (1972). On the first pass, the diver swam quite quickly $\left(>5 \mathrm{~m} \mathrm{~min}^{-1}\right)$ to record 'transient' fishes, which swam through the transect but consistently fled at the divers approach. On the second pass, the diver swam more slowly $\left(<1 \mathrm{~m} \mathrm{~min}^{-1}\right)$ to record more sedentary species. All individuals in each of eight different families (Acanthuridae, Chaetodontidae, Labridae, Pomacanthidae, Pomacentridae, Scaridae, Siganidae and Zanclidae) were recorded to species (Table 1).

Spatial variation in the community structure of coral reef fishes was analysed using correspondence analysis (CA), which compares the relative abundance of different fish spe-

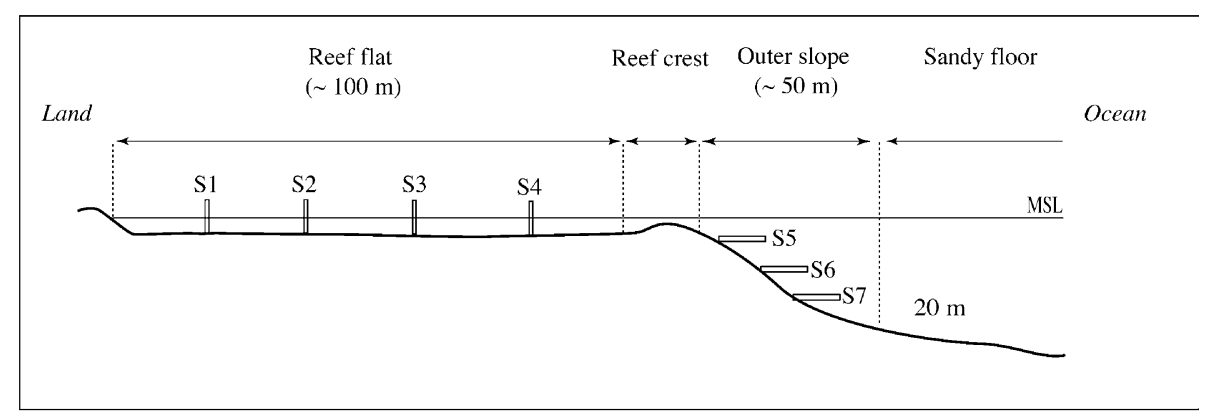

Fig. 2. Schematic view of cross-reef profile showing the position of stations within each location. Stations $1-4$ were placed equidistant across the reef flat, while stations 5, 6 and 7 were positioned according to depth (5,10 and $15 \mathrm{~m}$, respectively). 'MSL' indicates mean sea level. 
Table 1

One hundred and fifty-six species recorded during surveys across all three islands (Aka, Ishigaki and Sesoko)

\section{Pomacentridae (48 species)}

Abudefduf sexfasciatus

Abudefduf vaigiensis

Amblyglyphidodon curacao

Amblygliphidodon leucogaster

Amphiprion clarkii

Amphiprion frenatus

Amphiprion ocellaris

Amphiprion perideraion

Cheiloprion labiatus

Chromis atripectoralis

Chromis atripes

Chromis chrysura

Chromis flavomaculata

Chromis fumea

Chromis margaritifer

Chromis ovatiformes

Chromis ternatensis

Chromis viridis

Chromis xanthura

Chrysiptera cyanea

Chrysiptera glauca

Chrysiptera leucopoma

Chrysiptera rex

Chrysiptera starki

Dascyllus aruanus

Dascyllus reticulatus

Dascyllus trimaculatus

Dishistodus melanotus

Dishistodus prosopotaenia

Neoglyphidodon melas

Neoglyphidodon nigroris

Plectroglyphidodon dickii

Plectroglyphidodon johnstonianus

Plectroglyphidodon lacrymatus

Plectroglyphidodon leucozonus

Pomacentrus alexanderae

Pomacentrus amboinensis

Pomacentrus bankanensis

Pomacentrus chrysurus

Pomacentrus lepidogenys

Pomacentrus moluccensis

Pomacentrus philippinus

Pomacentrus vaiuli

Pomachromis richardsoni

Stegastes nigricans

Pomacentridae sp. 1

Pomacentridae sp. 2

Pomacentridae sp. 3

Labridae (44 species)

Anampses caeruleopunctatus

Anampses meleagrides

Anampses twistii

Bodianus axillaries

Bodianus hirsutus

Cheilinus chlororous

Cheilinus diagrammus

Cheilinus fasciatus

Cheilinus rhodochrous

\section{Cheilinus trilobatus}

Cheilio inermis

Cirrhilabrus cyanopleura

Coris aygula

Coris gaimard

Coris variegata

Epibulus insidiator

Gomphosus varius

Halichoeres hortulanus

Halichoeres margaritaceus

Halichoeres marginatus

Halichoeres melanochir

Halichoeres melanurus

Halichoeres prosopeion

Halichoeres trimaculatus

Hemigymnus fasciatus

Hemigymnus melapterus

Labrichthys unilineatus

Labroides bicolor

Labroides dimidiatus

Labropsis manabei

Macropharyngodon meleagris

Novaculichthys taeniorous

Oxycheilinus unifasciatus

Pseudocheilinus hexataenia

Stethojulis bandanensis

Stethojulis strigiventer

Thalassoma amblycephalum

Thalassoma hardwicke

Thalassoma jansenii

Thalassoma lunare

Thalassoma lutescens

Thalassoma quinquevittatum

Thalassoma trilobatum

Labridae sp.

Chaetodontidae (22 species)

Chaetodon argentatus

Chaetodon auriga

Chaetodon auripes

Chaetodon baronessa

Chaetodon bennetti

Chaetodon citrinellus

Chaetodon kleinii

Chaetodon lineolatus

Chaetodon lunula

Chaetodon melannotus

Chaetodon ornatissimus

Chaetodon plebeius

Chaetodon rafflesi

Chaetodon trifascialis

Chaetodon trifasciatus

Chaetodon ulietensis

Chaetodon unimaculatus

Chaetodon vagabundus

Forcipiger flavissimus

Heniochus chrysostomus

Heniochus singularius

Heniochus varius
Acanthuridae (14 species)

Acanthurus japonicus

Acanthurus lineatus

Acanthurus maculiceps

Acanthurus nigricans

Acanthurus nigrofuscus

Acanthurus pyroferus

Acanthurus triostegus

Ctenochaetus striatus

Naso lituratus

Naso unicornis

Zebrasoma flavescens

Zebrasoma scopas

Zebrasoma veliferum

Acanthuridae sp.

Scaridae (12 species)

Scarus bowersi

Scarus chameleon

Scarus festivus

Scarus forsteni

Scarus javanicus

Scarus niger

Scarus oviceps

Scarus psittacus

Scarus rivulatus

Scarus schlegeli

Scarus sordidus

Scarus spinus

Pomacanthidae (10 species)

Centropyge bispinosa

Centropyge ferrugata

Centropyge heraldi

Centropyge tibicen

Centropyge vrolicki

Chaetodontoplus mesoleucus

Genicanthus lamarck

Pomacanthus imperator

Pomacanthus semicirculatus

Pygoplites diacanthus

Siganidae (five species)

Siganus corallinus

Siganus puellus

Siganus spinus

Siganus unimaculatus

Siganus virgatus

Zanclidae (one species)

Zanclus cornutus 
cies among stations and among locations (Benzécri, 1973). Results of the analysis were then displayed in a bi-plot to show relative similarities in the structure of fish communities among stations and among islands. If coral reef fish communities are structured according to strong environmental gradients that extend across the fringing reef, we would expect to find stations arranged in approximate order (1-7) across the bi-plot. Alternatively, stations may be arranged in distinct clusters, indicating marked changes in community structure from one group of stations to the next. Spatial patterns in the structure of fish communities were confirmed using hierarchical clustering, which searches the data for distinct 'clusters' of stations with similar fish communities. The clustering algorithm used in this study was based on Ward's method of minimum variance clustering. Where clusters were identified, variation between clusters was then compared to variation within each cluster, using Wilks' test (Wilks, 1932). If variation between clusters is significantly greater than variation within clusters, then the designated clusters will provide significant information on the spatial structure of fish communities, if not, then clusters were considered invalid and the respective clusters merged.

To assess the influence of environmental variables on the distribution of coral reef fishes, the abundance and species richness of reef corals (biological variables), as well as water depth, distance from the shoreline, and reef zone (physical variables) were recorded for every station at each location. Coral abundance (number of coral colonies per $\mathrm{m}^{2}$ ) and coral richness (number of species per $\mathrm{m}^{2}$ ) were quantified using replicate $10 \times 1 \mathrm{~m}$ belt transects (Table 2 ). Three replicate transects were run parallel to the shoreline within each station, and the absolute numbers of adult coral colonies (colonies $>5 \mathrm{~cm}$ diameter) as well as the number of different coral species were recorded for each transect. Mean water depth and distance from the shoreline were recorded at each station were also measured for every transect. The reef zone (reef flat vs. outer slope) was entered as a categorical variable, where reef flat $=1$, and outer slope $=2$. Multivariate analysis of correlations between fish communities and environmental variables (coral cover, coral richness, depth, distance from the shore, and reef zone) was then conducted using canonical correspondence analysis (CCA), following ter Braak (1986). Analyses were conducted at the level of stations $(n=21$ stations), rather than individual transects (cf. CA of fish communities), and so steps had to be taken to maximise the power of the CCA: most importantly, not all environmental variables could be used in the CCA, and so variables to be used in the analysis were selected using a permutation test. During this stepwise procedure (analogous to backward elimination in multiple regression) various combinations of the five different variables (coral cover, coral richness, depth, distance from the shore, and reef zone) were tested to determine which combination of variables best explained observed variation in the structure of fish communities (ter Braak, 1986). After the best combination of variables was selected, the CCA was run to determine the degree to which the model would best explain the structure of coral reef fish communities.

The robustness of the final analysis was then determined using the Monte Carlo permutation test (ter Braak, 1986).

\section{Results}

\subsection{Spatial patterns in fish communities}

A total of 21356 fishes were recorded across all 63 transects sampled, corresponding to a mean density of 2.26

Table 2

Mean abundance (number of individuals per $\mathrm{m}^{2}$ ) and species richness (number of total species-data in parenthesis) of reef fishes at each zone ( $\left.\mathrm{S} 1-7\right)$, and each island (Ishigaki, Aka and Sesoko, ordered from south to north). The mean abundance (number of individuals per $\mathrm{m}^{2}$ ) and mean species richness (number of species per $\mathrm{m}^{2}$ ) of coral colonies were also given for each zone and each island

\begin{tabular}{|c|c|c|c|c|c|c|c|c|c|c|c|}
\hline Family & $\mathrm{S} 1$ & $\mathrm{~S} 2$ & $\mathrm{~S} 3$ & $\mathrm{~S} 4$ & S5 & S6 & S7 & Ishigaki & Aka & Sesoko & Total \\
\hline Acanthuridae & $0.0341(4)$ & $\begin{array}{l}0.00437 \\
(5)\end{array}$ & $0.0771(6)$ & $0.2230(9)$ & $0.0926(7)$ & $0.0971(7)$ & $0.1341(6)$ & $\begin{array}{l}0.1041 \\
(10)\end{array}$ & $0.1200(7)$ & $0.0765(9)$ & $0.1002(14)$ \\
\hline Chaetodontidae & 0.0074 & $0.0178(8)$ & $0.0141(7)$ & $0.0378(6)$ & $\begin{array}{l}0.0526 \\
(15)\end{array}$ & $\begin{array}{l}0.0563 \\
(13)\end{array}$ & $0.0437(9)$ & $\begin{array}{l}0.0267 \\
(14)\end{array}$ & $\begin{array}{l}0.0349 \\
(15)\end{array}$ & $\begin{array}{l}0.0368 \\
(14)\end{array}$ & $0.0328(22)$ \\
\hline Pomacanthidae & $0(0)$ & $0(0)$ & $0(0)$ & $0.0022(1)$ & $0.0126(2)$ & $0.0237(6)$ & $0.0281(4)$ & $0.0009(2)$ & $0.0114(4)$ & $0.0162(7)$ & $0.0095(10)$ \\
\hline Pomacentridae & $\begin{array}{l}1.4981 \\
(13)\end{array}$ & $\begin{array}{l}1.4981 \\
(14)\end{array}$ & $\begin{array}{l}2.6703 \\
(16)\end{array}$ & $\begin{array}{l}1.3963 \\
(13)\end{array}$ & $\begin{array}{l}3.4463 \\
(26)\end{array}$ & $\begin{array}{l}1.9797 \\
(23)\end{array}$ & $\begin{array}{l}1.3129 \\
(21)\end{array}$ & $\begin{array}{l}2.7317 \\
(23)\end{array}$ & $\begin{array}{l}1.8215 \\
(33)\end{array}$ & $\begin{array}{l}1.3619 \\
(34)\end{array}$ & $1.9717(48)$ \\
\hline Scaridae & $0.0104(1)$ & $0.0081(2)$ & $0.0059(2)$ & $0.0830(4)$ & $0.0400(7)$ & $0.0274(9)$ & $0.0378(9)$ & $0.0407(9)$ & $0.0349(7)$ & $0.0155(6)$ & $0.0304(12)$ \\
\hline Siganidae & $0.0037(3)$ & $0.0422(1)$ & $0.0659(2)$ & $0.0029(1)$ & $0.0045(1)$ & $0.0155(3)$ & $0.0037(1)$ & $0.0105(3)$ & $0.0003(1)$ & $0.0486(1)$ & $0.0198(5)$ \\
\hline Zanclidae & $0.0015(1)$ & $0.0029(1)$ & $0.0015(1)$ & $0.0037(1)$ & $0.0081(1)$ & $0.0037(1)$ & $0.0037(1)$ & $0.0019(1)$ & $0.0031(1)$ & $0.0057(1)$ & $0.0036(1)$ \\
\hline All families & $\begin{array}{l}1.6248 \\
(38)\end{array}$ & $\begin{array}{l}1.7707 \\
(47)\end{array}$ & $\begin{array}{l}2.9859 \\
(52)\end{array}$ & $\begin{array}{l}1.8622 \\
(55)\end{array}$ & $\begin{array}{l}3.7078 \\
(66)\end{array}$ & $\begin{array}{l}2.2737 \\
(81)\end{array}$ & $\begin{array}{l}1.5937 \\
(71)\end{array}$ & $\begin{array}{l}2.9749 \\
(90)\end{array}$ & $\begin{array}{l}2.1315 \\
(97)\end{array}$ & $\begin{array}{l}1.6730 \\
(98)\end{array}$ & $\begin{array}{l}2.2599 \\
(156)\end{array}$ \\
\hline $\begin{array}{l}\text { Coral } \\
\text { abundance }\end{array}$ & 1.01 & 4.52 & 8.57 & 11.11 & 14.76 & 9.0 & 8.17 & 13.57 & 13.77 & 13.38 & 13.57 \\
\hline Coral richness & 0.74 & 1.53 & 2.01 & 2.25 & 4.77 & 4.52 & 4.23 & 2.79 & 2.82 & 2.68 & 2.76 \\
\hline
\end{tabular}



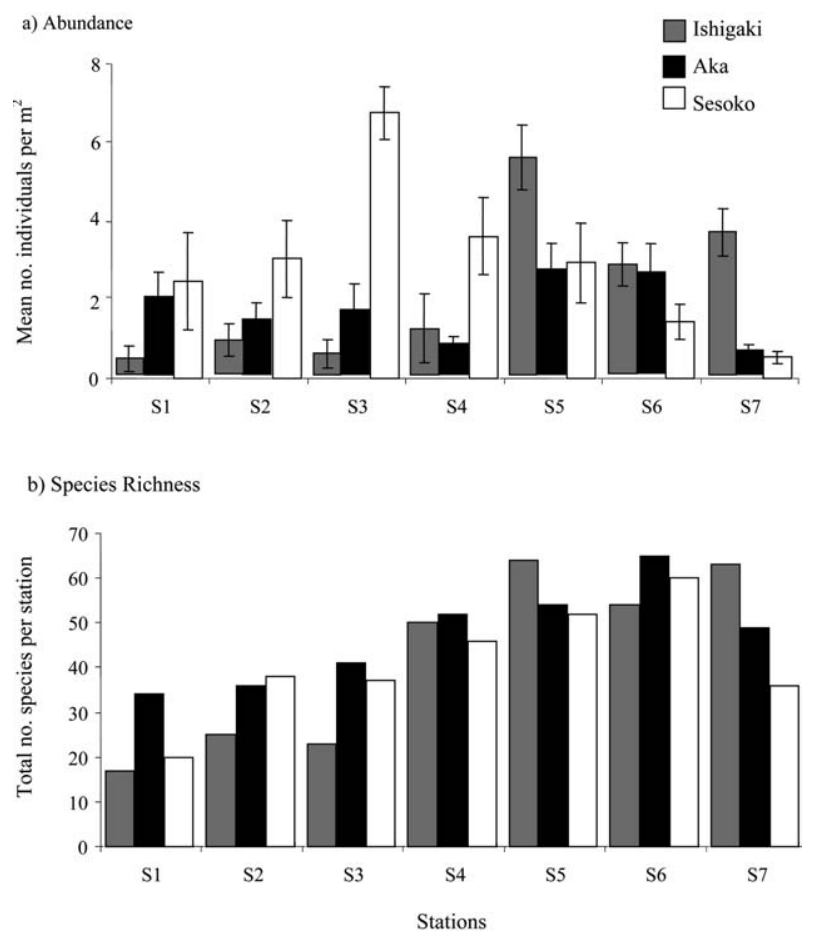

Fig. 3. Variation in (a) mean abundance (number of individuals per $\mathrm{m}^{2}$ ) and (b) species richness of coral reef fishes among stations and among reefs (the three islands were ordered from south to north). Error bars represent one standard error.

( \pm 0.20 S.E.) fishes per $\mathrm{m}^{2}$. Mean densities of fishes varied almost twofold among locations, ranging from $2.97( \pm 0.64$ S.E.) fishes per $\mathrm{m}^{2}$ at Ishigaki, compared to 2.13 ( \pm 0.64 S.E.) fishes per $\mathrm{m}^{2}$ at Aka, and 1.67 ( \pm 0.54 S.E.) fishes per $\mathrm{m}^{2}$ at Sesoko. Within locations, mean densities of reef fishes varied greatly among stations, but there was no consistent change in abundance from the inner reef flat to the outer slope (Fig. 3a). The majority of fishes recorded at every station were from the family Pomacentridae (Table 2). In all, pomacentrids accounted for $87 \%$ (18 632/21 356) of all individuals counted, and were an order of magnitude more abundant $(x=1.97 \pm$ 0.21 S.E. fishes per $\mathrm{m}^{2}$ ) than the next most abundant families, which were the Acanthuridae $(x=0.10 \pm 0.01$ S.E. fishes per $\left.\mathrm{m}^{2}\right)$ and Labridae $\left(x=0.09 \pm 0.008\right.$ S.E. fishes per $\left.\mathrm{m}^{2}\right)$. The overall fish community comprised a total of 156 different species, from 46 different genera (Table 1). Species richness varied little among locations (Aka, 98 species; Ish, 100 species; Ses, 87 species), but showed a fairly clear and consistent increase from the inner reef flat to the outer slope (Fig. 3b). The most speciose families (Table 2) were the Pomacentridae (48 species), Labridae (44 species) and Chaetodontidae (22 species).

Spatial variation in the community structure of coral reef fishes was analysed using two separate analyses; the first analysis considered only the Pomacentridae, while the second analysis considered all other families (Acanthuridae, Chaetodontidae, Labridae, Pomacanthidae, Scaridae, Siganidae and Zanclidae). The results from these two analyses were largely complementary, but when all families were

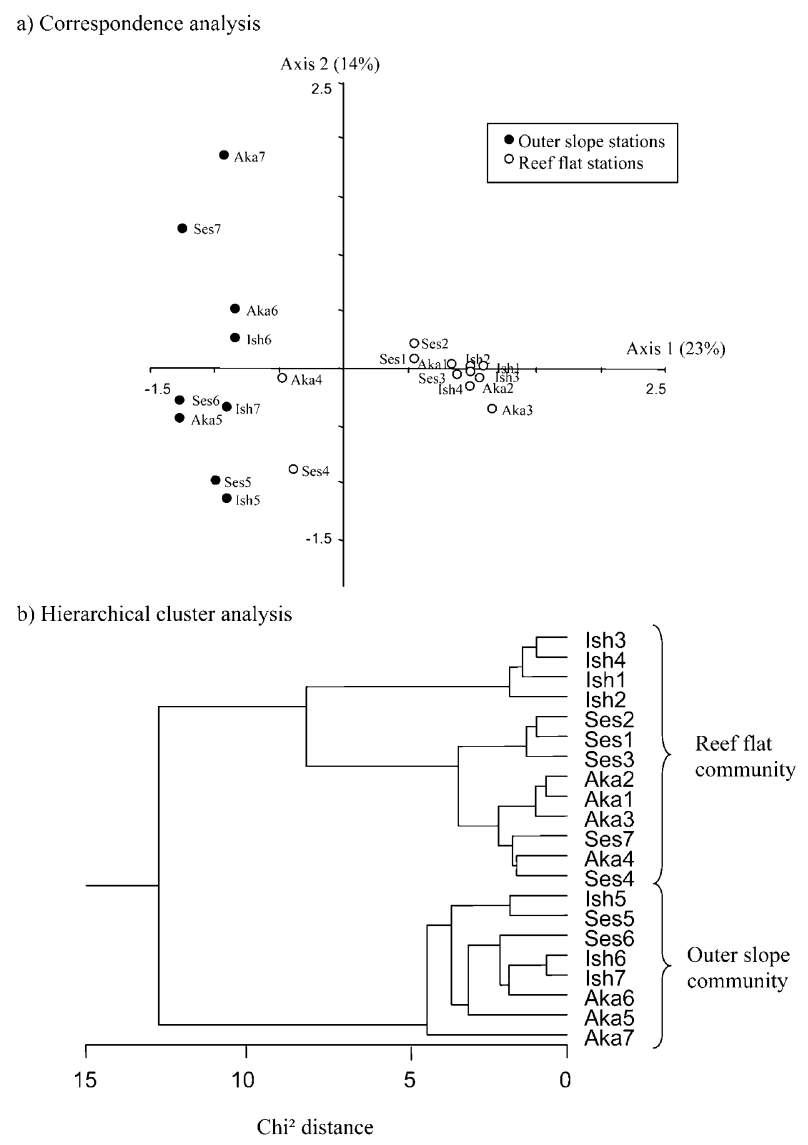

Fig. 4. CA and hierarchical clustering analysis showing spatial structure in the distribution of 48 species from the family Pomacentridae. Plots of the CA show ordination along the first two axes (the inertia of each axis is given). Stations are coded according to island (Aka, Aka; Ishigaki, Ish; Sesoko, Ses) and position along the cross-shelf profile (1-7).

considered together the results were indistinguishable from results of the analysis in which the Pomacentridae were considered alone (i.e. the Pomacentridae were shown to be swamping the dataset and thereby obscuring differences in the relative abundance of all other fish species). The independent analysis (CA) of community structure for the Pomacentridae showed strong separation of most reef flat stations (all except Ses4 and Aka4) from outer slope stations (Fig. 4a). This result shows that variability among stations (within locations) was much greater than variability among islands (among locations). Moreover, the community is organised into two distinct assemblages, rather than exhibiting gradual change in community structure along the cross-reef gradient. Hierarchical clustering further confirmed the separation of two distinct assemblages but the grouping of stations was somewhat different to that expected from the CA (Fig. 4b); the first cluster comprised all reef flat stations (including Ses4 and Aka4) as well as station Ses 7, while the second cluster comprised all remaining outer slope stations. Variation in community structure between these clusters was significantly higher than variability within each cluster (Wilks' test, $F=16.38, \mathrm{df}=18, P=0.05$ ). The reef flat assemblage of pomacentrid fishes (as distinguished by hierarchical cluster- 


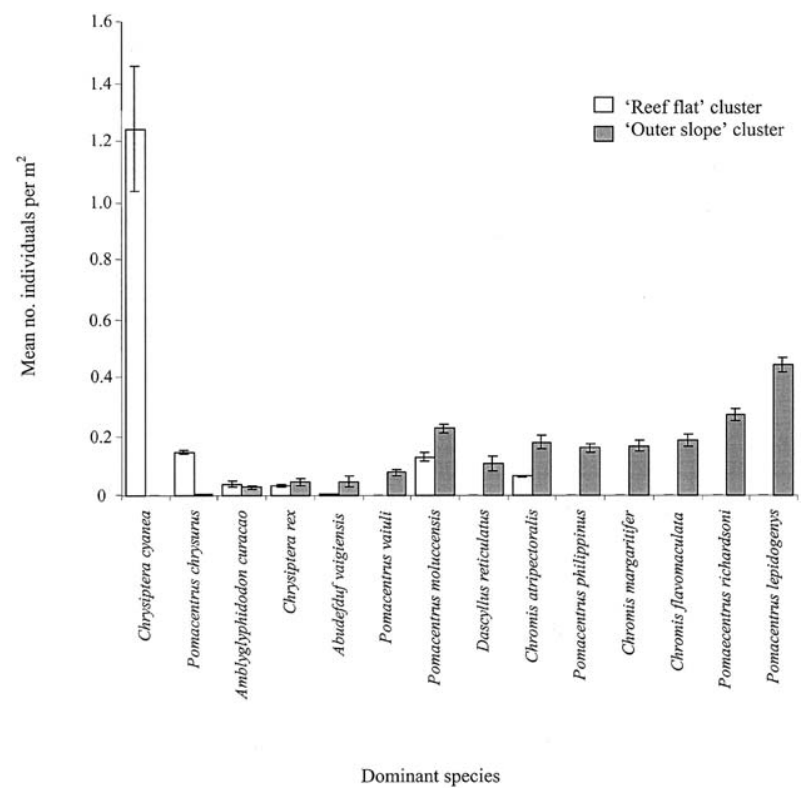

Fig. 5. Variation in the abundance of the 14 most common species of Pomacentridae relative to 'clusters' identified in hierarchical clustering analysis. The 'reef flat' cluster includes all reef flat stations, as well as station Aka7. The outer slope cluster includes all outer slope stations except Aka7. Error bars represent 1 S.E.

ing) was dominated by Chrysiptera cyanea, but also characterised by high densities of Pomacentrus chrysurus. In comparison, the outer slope assemblages of pomacentrids were characterised by high densities of Pomacentrus lepidogenys and $P$. richardsoni as well as a number of other Pomacentrus and Chromis species (Fig. 5).

Analysis of spatial structure in communities of nonpomacentrid reef fishes (Acanthuridae, Chaetodontidae, Labridae, Pomacanthidae, Scaridae, Siganidae and Zanclidae) also revealed apparent separation of reef flat communities from outer slope communities (Fig. 6a). Hierarchical clustering confirmed the occurrence of two distinct clusters; the first cluster comprised nearly all the reef flat stations, while the second cluster comprised all outer slope stations, as well as Aka4 and Ish4 (Fig. 6b). These two clusters were significantly different in their community structure (Wilks' test, $F=27.69$, df $=18, P=0.03$ ). The reef flat cluster (as identified by hierarchical clustering) was dominated by Acanthurus nigrofuscus, and also had high densities of Siganus spinus, Halichoeres trimaculatus and Thalassoma hardwicke, whereas the outer slope cluster was dominated by Ctenochaetus striatus, and also had high densities of $A$. nigrofuscus as well as Chaetodon trifasciatus (Fig. 7). At the family level, only the Labridae and Siganidae were found in significantly higher abundance on the reef flat compared to the outer slope. All other families (Chaetodontidae, Pomacanthidae, Scaridae, Zanclidae and Acanthuridae) were much more abundant on the reef slope than on the reef flat; Pomacanthidae were found only on the outer slope, and virtually all the Zanclidae were seen on the outer slope (Fig. 8). The dominant family of reef fish found on the reef flat a) Correspondence analysis
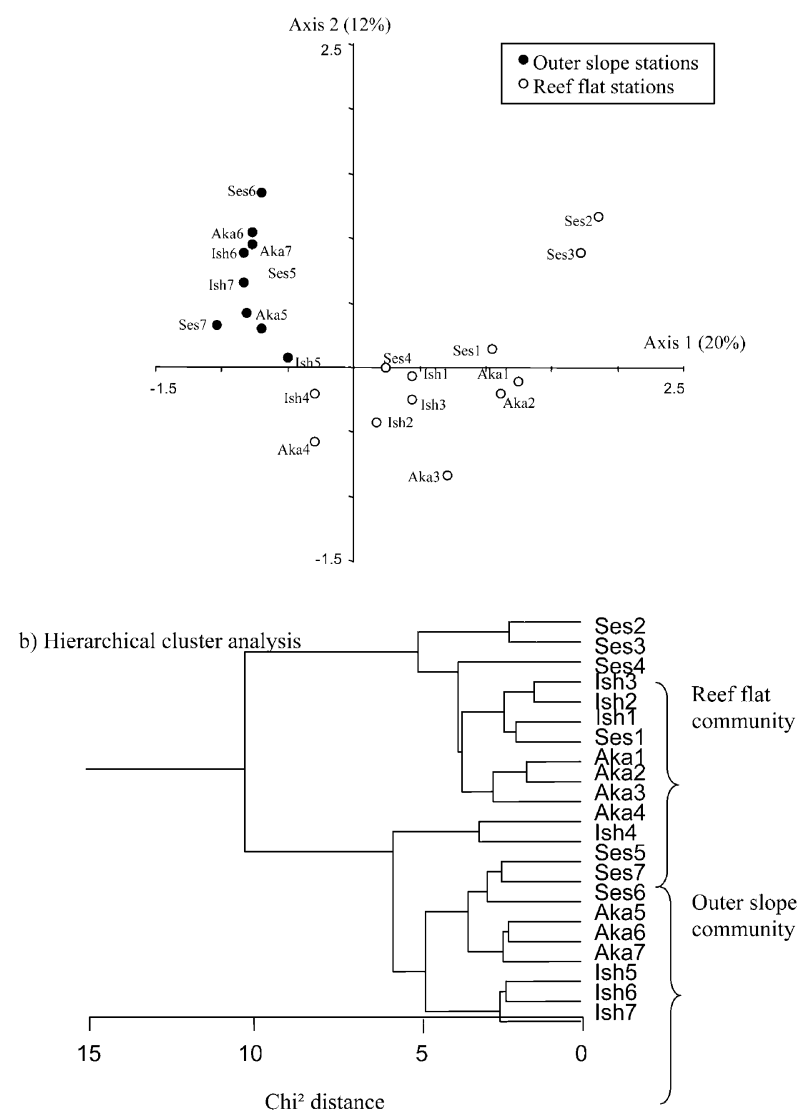

Fig. 6. CA and hierarchical clustering analysis showing spatial structure in the distribution of 108 species from the families Acanthuridae, Chaetodontidae, Labridae, Pomacanthidae, Scaridae, Siganidae, and Zanclidae. Plots of the CA show ordination along the first two axes (the inertia of each axis is given). Stations are coded according to island (Aka, Aka; Ishigaki, Ish; Sesoko, Ses) and position along the cross-shelf profile (1-7).

(excluding the Pomacentridae) were the Labridae, whereas the Acanthuridae dominated the outer slope (Fig. 8).

Correlations between spatial patterns of fish communities and environmental factors (abundance of corals, species richness of corals, water depth, distance from the shoreline, and reef zone) were assessed using CCA. Once again, independent analyses were conducted for (i) the Pomacentridae, and (ii) all other families (Acanthuridae, Chaetodontidae, Labridae, Pomacanthidae, Scaridae, Siganidae and Zanclidae). The CCA for the Pomacentridae revealed that the most significant factors explaining variation in community structure were reef zone and water depth. These two variables explained $32.8 \%$ of variance in the species matrix for the Pomacentridae (Table 3). Moreover, the addition of other environmental variables (abundance of corals, species richness of corals, and distance from the shoreline) did not increase the proportion of variation that could be explained by these environmental factors. Similarly, in the CCA for the seven non-pomacentrid families only two variables, distance from the coast and the water depth, were significant in explaining spatial variation in community structure. These two 


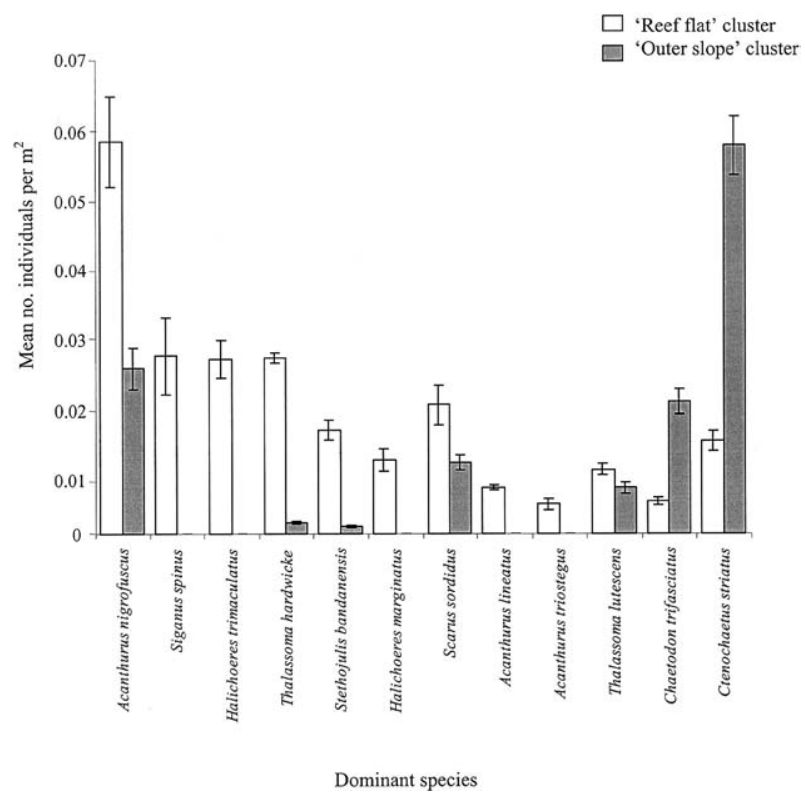

Fig. 7. Variation in the abundance of the 12 most common species of Acanthuridae, Chaetodontidae, Labridae, Pomacanthidae, Scaridae, Siganidae, and Zanclidae relative to 'clusters' identified in hierarchical clustering analysis. The 'reef flat' cluster includes all reef flat stations, except Aka4 and Ish4. The outer slope cluster includes all outer slope stations, as well as stations Aka4 and Ish4. Error bars represent 1 S.E.

variables accounted for $23.6 \%$ of variance in the species matrix for non-pomacentrid fishes (Table 4).

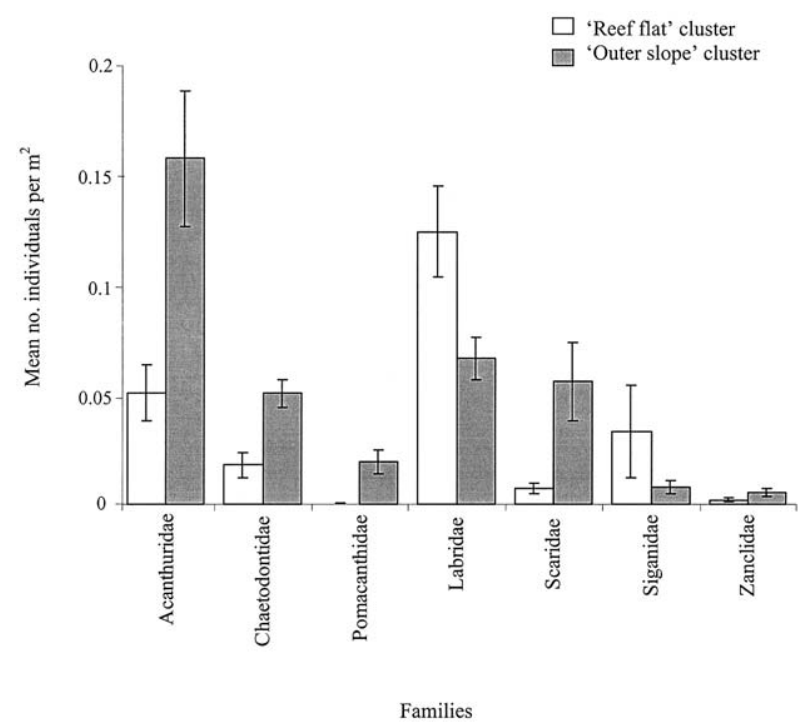

Fig. 8. Variation in the overall abundance of each family (Acanthuridae, Chaetodontidae, Labridae, Pomacanthidae, Scaridae, Siganidae and Zanclidae) relative to 'clusters' identified in hierarchical clustering analysis. The 'reef flat' cluster includes all reef flat stations, except Aka4 and Ish4. The outer slope cluster includes all outer slope stations, as well as stations Aka4 and Ish4. Error bars represent 1 S.E.
Table 3

Summary of the CCA performed on community structure of fishes from the family Pomacentridae. Significant factors were selected using backward elimination permutation tests (number of permutations $=199$ ). The robustness of the analysis was tested using a Monte Carlo test

\begin{tabular}{|c|c|c|}
\hline & Axis $\mathrm{f} 1$ & Axis $\mathrm{f} 2$ \\
\hline \multicolumn{3}{|l|}{$\begin{array}{l}\text { Correlations of environmental variables with } \\
\text { ordination axes }\end{array}$} \\
\hline (1) Depth & 0.762 & 0.586 \\
\hline (2) Reef zone & -0.979 & -0.013 \\
\hline \multicolumn{3}{|l|}{ Summary statistics for ordination axes } \\
\hline Eigenvalues & 0.807 & 0.422 \\
\hline Species-environment correlations & 0.979 & 0.934 \\
\hline \multicolumn{3}{|l|}{ Cumulative percentage variance } \\
\hline of species data & 21.6 & 32.8 \\
\hline of species-environment relation & 62.7 & 100 \\
\hline Sum of all unconstrained eigenvalues & 3.744 & \\
\hline Sum of all canonical eigenvalues & 1.229 & \\
\hline $\begin{array}{l}\text { Monte Carlo probability for significance of all } \\
\text { eigenvalues: } 0.001\end{array}$ & & \\
\hline
\end{tabular}

\section{Discussion}

\subsection{Species richness and abundance of coral reef fishes}

The species richness of coral reef fishes recorded in the Ryukyu Islands (156 species across the eight different families) was very high compared to the species richness recorded during similar studies (and on a similar sampled area) for the central Pacific (Moorea, Galzin, 1987-98 species with 42 families sampled) and Indian Ocean (Mauritius, Adjeroud et al., 1998-107 species with 32 families sampled). This high diversity is particularly interesting considering the geographic extreme of the Ryukyus and generally small size of islands considered during this study. The Ryukyu Islands represent the northernmost reefs in the world and one may predict that diversity of coral reef fishes should be reduced at their northern extreme (Veron and Minchin, 1992). More-

Table 4

Summary of the CCA performed on community structure of fishes from non-Pomacentridae families (Acanthuridae, Chaetodontidae, Labridae, Pomacanthidae, Scaridae, Siganidae and Zanclidae). Significant factors were selected using backward elimination permutation tests (number of permutations $=199$ ). The robustness of the analysis was tested using a Monte Carlo test

\begin{tabular}{|c|c|c|}
\hline & Axis $\mathrm{f} 1$ & Axis $\mathrm{f} 2$ \\
\hline \multicolumn{3}{|l|}{$\begin{array}{l}\text { Correlations of environmental variables with } \\
\text { ordination axes }\end{array}$} \\
\hline (1) Depth & -0.771 & 0.529 \\
\hline (2) Distance from the coast & -0.944 & 0.112 \\
\hline \multicolumn{3}{|l|}{ Summary statistics for ordination axes } \\
\hline Eigenvalues & 0.546 & 0.219 \\
\hline Species-environment correlations & 0.952 & 0.903 \\
\hline \multicolumn{3}{|l|}{ Cumulative percentage variance } \\
\hline of species data & 16.8 & 23.6 \\
\hline of species-environment relation & 71.4 & 100 \\
\hline Sum of all unconstrained eigenvalues & 3.242 & \\
\hline Sum of all canonical eigenvalues & 0.765 & \\
\hline $\begin{array}{l}\text { Monte Carlo probability for significance of all } \\
\text { eigenvalues: } 0.001\end{array}$ & & \\
\hline
\end{tabular}


over, local diversity of coral reef fishes is generally correlated with the size of the reef (Galzin et al., 1994), and thus it would be expected that the Ryukyu Islands would support low diversity assemblages of coral reef fishes. The high diversity of coral reef fishes observed in the Ryukyu Islands is attributable, at least in part, to the strong northerly Kuroshio current that furnishes this area with warm equatorial waters, thus improving the ecological conditions for the growth and survivorship of coral reef organisms (Cadoret et al., 1999). Moreover, the Kuroshio current is likely to provide a high diversity of fish recruits direct from the IndoPacific Archipelago, the centre of diversity for coral reef fishes (Sale, 1980). Indeed, the high degree of connectivity between the Indo-Pacific Archipelago and coral reefs in southern Japan has led several researchers to consider the Ryukyus within the centre of diversity for coral reef fishes (Thresher, 1991).

Despite the high species richness of coral reef fishes in the Ryukyu Islands, the abundance of coral reef fishes was generally lower than that observed on coral reefs elsewhere throughout the world (see also Cadoret et al., 1999). For example, the mean abundance of Chaetodontidae recorded across all three islands considered during this study (Aka, Ishigaki and Sesoko) was just 0.03 fishes per $\mathrm{m}^{2}$. In contrast, Findley and Findley (1985) recorded densities of butterfly fish in French Polynesia, Australia and the Red Sea that correspond to $0.21,0.13$ and 0.14 fishes per $\mathrm{m}^{2}$, respectively (see also Fowler, 1990; Bouchon-Navaro, 1981; BouchonNavaro and Bouchon, 1989). Mean densities of butterfly fish recorded in the Ryukyus Islands were comparable to densities recorded in the Caribbean (0.03 fishes per $\left.\mathrm{m}^{2}\right)$, where there are only three species of Chaetodontidae (Findley and Findley, 1985). Mean densities of fishes from other nonPomacentridae families (principally, the Labridae, Scaridae and Acanthuridae) were also much lower than expected for coral reefs in the Pacific Ocean, whereas densities of Pomacentridae were somewhat higher than expected (cf. Munday and Jones, 1998).

\subsection{Structure of fish communities}

Coral reef fish communities observed in the Ryukyu Islands were characterised by an over-riding dominance (both in terms of abundance and species richness) of fishes from the family Pomacentridae. The Pomacentridae are often among the most abundant and most speciose families of fishes within coral reef systems (Williams, 1982). However, no other studies have shown the Pomacentridae to be more than an order of magnitude more abundant than the Acanthuridae, Labridae, Scaridae or Chaetodontidae (see Table 2). The numerical dominance of the Pomacentridae over all other reef fish families (Acanthuridae, Chaetodontidae, Labridae, Pomacanthidae, Scaridae, Siganidae, and Zanclidae) within the Ryukyu Islands may be attributable to overfishing of larger fish species (mainly Labridae, Scaridae and Acanthuridae) (Nishihira, 1987), coinciding with wide-spread habitat degradation (Sano, 2001). Both overfishing and habi- tat degradation would tend to have a disproportionate impact on larger fish species (Ohman et al., 1997), possibly explaining the lower than expected densities of Acanthuridae, Chaetodontidae, Labridae, Pomacanthidae, Scaridae, Siganidae and Zanclidae. It appears thus far, that the Pomacentridae have been largely unaffected by habitat degradation (if that is indeed what caused declines in the abundance of other fish families) but continued habitat degradation is likely to effect even the Pomacentridae (Sano et al., 1987).

The community structure of coral reef fishes was very consistent among the three islands considered in this study (Aka, Ishigaki and Sesoko), but varied greatly among stations within islands. Most notably, distinct communities of coral reef fishes were observed on the reef flat and outer slope. Variation in the community structure of coral reef organisms (both fishes and sessile invertebrates) among physiographic reef zones is one of the most striking patterns observed in coral reef environments, and has been noted on numerous occasions (see review by Williams, 1991 and references therein). The distinction between different assemblages in each reef zone (the reef flat vs. outer slope), observed during this study, was caused by highly restricted patterns of zonation for most fish species. There was evidence of higher diversity on the outer slope (compared to the reef flat), caused by the addition of species across the reef profile. However, many species were found only on the reef flat (e.g. Pomacentridae: C. cyanea, Cheioprion labiatus, Stegastes nigricans, Labridae: $H$. trimaculatus, Siganidae: $S$. spinus) or only on the outer slope (e.g. Pomacentridae: Chromis margaritifer, Dascyllus reticulatus, Chaetodontidae: Chaetodon auriga). At the family level, the Labridae and Siganidae were most abundant on the reef flat, whereas the Acanthuridae, Chaetodontidae, Pomacanthidae, Scaridae and Zanclidae were most abundant on the outer slope.

The distribution of fishes among reef zones may be related to the distribution of prey, habitat availability or the physiological capabilities of individual species relative to environmental conditions (Williams, 1991). In the case of herbivorous fishes, different patterns of zonation were found for each family (i.e. the Siganidae were found predominantly on the reef flat, whereas the Acanthuridae and Scaridae were found predominantly on the outer slope) and this may represent resource partitioning to minimise inter-familial competition (Choat and Bellwood, 1985). Our finding that the Chaetodontidae tended to be more abundant on the outer slope is similar to that of other studies, and is generally attributed to higher coral cover and higher topographic complexity found in this zone (Bouchon-Navaro et al., 1985; Bouchon-Navaro and Bouchon, 1989). Similarly, the Pomacanthidae were found only on the outer slope, and this is probably related to availability of shelter, rather than food (Allen et al., 1998). However, detailed accounts of observed distributions for individual species, or families, would require a detailed study of their biology, morphology and physiology (Bellwood and Wainwright, 2001). 


\subsection{Influence of environmental factors}

Of the five environmental variables considered during this study (abundance of corals, species richness of corals, water depth, distance from the shoreline, and reef zone), only the physical variables (water depth, distance from the shoreline, and reef zone) were shown to account for a significant proportion of variation in the structure of coral reef fishes. Interestingly, this study found that spatial variation in the structure of fish communities was not related to spatial variation in either coral abundance or coral richness. This is a stark contrast to the findings of many other studies of spatial variation in the community structure and distributions of coral reef fish (Fowler, 1990; Galzin et al., 1994; Chabanet et al., 1997). However, the lack of correlations between coral reef fish communities and coral abundance, and coral richness, does not necessarily mean that these factors are unimportant in structuring fish communities in the Ryukyus. In fact, biological, physical and historical factors may co-vary (through indirect or synergistic effects) in such a manner that potentially important factors are not revealed by CCA (Dunson and Travis, 1991). Moreover, seemingly unimportant environmental variables (e.g. coral abundance) may have a significant influence on a small subset of species (e.g. the Chaetodontidae), but appear relatively unimportant when looking at community-level responses. For example, Cadoret et al. (1999) examined the community structure of just the Chaetodontidae in the Ryukyu Islands, and found a significant association with live coral cover (see also BouchonNavaro, 1981; Bouchon-Navaro and Bouchon, 1989).

The factors considered in each of the two separate analysis (Pomacentridae, reef zone and water depth; other families, distance from the coast and water depth) accounted for a significant, but only relatively small portion of spatial variation (32.8\% and $23.6 \%$, respectively) in the structure of these communities. The remaining 'unexplained' portion of the variation is attributable to pure spatial variation (the amount of spatial structuring in the species matrix), and variation due to environmental factors not measured in this study. This study considered only a very small number of the potential factors that might influence the spatial structure of coral reef fish communities (e.g. substrate complexity, wave exposure, species interactions) and though it is not feasible to consider all possible factors in a single study, these findings may point to other factors that are likely to be important in structuring fish communities. Conspicuous zone related differences in the community structure of coral reef fishes, as were observed in the Ryukyu Islands, have mostly been attributed to variation in wave exposure and water movement (e.g. Williams, 1982; Galzin, 1987; Adjeroud et al., 1998; Bellwood and Wainwright, 2001; Fulton et al., 2001). However, wave exposure and water movement also vary with respect to distance from the shoreline and water depth (Denny, 1988). Therefore, hydrodynamic conditions may represent the causal mechanism behind the correlations with reef zone, water depth and distance from the shoreline, detected during this study.

In conclusion, this study has shown that coral reef fish communities appear fairly homogenous among islands in the Ryukyu Archipelago. However, there were significant differences in the structure of fish communities between reef zones. In contrast to most previous studies (Chabanet et al., 1997), variation in the structure of fish communities appeared largely unrelated to coral abundance or coral diversity. Rather, coral reef fish communities appeared to be structured according to spatial variation in physical variables, which was probably related to wave exposure and water movement (Bellwood and Wainwright, 2001). The overall fish community of the Ryukyus was very diverse, but the individual abundance of most major families (Acanthuridae, Chaetodontidae, Labridae and Scaridae) was unexpectedly low. These findings may highlight the wide-spread anthropogenic impacts (overfishing, industrialisation) combined with natural disturbances (outbreaks of crown-of-thorns starfish, coral bleaching) that have affected coral reefs throughout southern Japan (Nishihira, 1987; Sano, 2001). It would be important, therefore, to conduct a follow-up study to assess whether there have been any further changes in coral reef fish communities of the Ryukyu Islands, indicative of ongoing impacts to these reef systems.

\section{Acknowledgements}

We gratefully acknowledge assistance received from Professor Makoto Tsuchiya and from the staff at Ishigaki Tropical Station, Akajima Marine Science Laboratory, Sesoko Station and the Department of Chemistry, Biology and Marine Science at the University of the Ryukyus. M. Adjeroud was supported by a postdoctoral fellowship from the Japan Society from the Promotion of Science.

\section{References}

Adjeroud, M., Letourneur, Y., Porcher, M., Salvat, B., 1998. Factors influencing spatial distribution of fish communities on a fringing reef at Mauritius, S.W. Indian Ocean. Environ. Biol. Fish. 53, 169-182.

Allen, G.R., Steene, R., Allen, M., 1998. A Guide to Angelfishes and Butterflyfishes. Odyssey Publishing, Perth.

Bell, J.D., Harmelin-Vivien, M., Galzin, R., 1985. Large scale spatial variation in abundance in butterflyfishes (Chaetodontidae) on Polynesian reefs. Proc. 5th Int. Coral Reef Symp. 5, 421-426.

Bellwood, D.R., Wainwright, P.C., 2001. Locomotion in labrid fishes: implications for habitat use and cross-shelf biogeography on the Great Barrier Reef. Coral Reefs 20, 139-150.

Benzécri, J.P., 1973. L'analyse des correspondances. Dunod, Paris.

Booth, D.J., 2002. Distribution changes after settlement in six species of damselfish (Pomacentridae) in One Tree Island lagoon, Great Barrier Reef. Mar. Ecol. Prog. Ser. 226, 157-164.

Booth, D.J., 1995. Juvenile groups in a coral-reef damselfish: density dependent effects on individual fitness and population demography. Ecology 76, 91-106. 
Bouchon-Navaro, Y., 1981. Quantitative distribution of the Chaetodontidae on a reef off Moorea Island (French Polynesia). J. Exp. Mar. Biol. Ecol. $55,145-157$.

Bouchon-Navaro, Y., Bouchon, C., 1989. Correlations between chaetodontid fishes and coral communities of the Gulf of Aqaba (Red Sea). Environ. Biol. Fish. 25, 47-60.

Bouchon-Navaro, Y., Bouchon, C., Harmelin-Vivien, M.L., 1985. Impact of coral degradation on a Chaetodontid fish assemblage (Moorea, French Polynesia). Proc. 5th Int. Coral Reef Symp. 5, 427-432.

Cadoret, L., Legendre, P., Adjeroud, M., Galzin, R., 1995. Répartition spatiale des Chaetodontidae dans différents secteurs récifaux de l'île de Moorea, Polynésie française. Ecoscience 2, 129-140.

Cadoret, L., Adjeroud, M., Tsuchiya, M., 1999. Spatial distribution of chaetodontid fish in coral reefs of the Ryukyu Islands, southern Japan. J. Mar. Biol. Assoc. UK 79, 725-735.

Caley, M.J., Carr, M.H., Hixon, M.A., Hughes, T.P., Jones, G.P., Menge, B.A., 1996. Recruitment and the local dynamics of open marine populations. Ann. Rev. Ecol. Syst. 27, 477-500.

Caselle, J.E., 1999. Early post-settlement mortality in a coral reef fish and its effect on local population size. Ecol. Monogr. 69, 177-194.

Choat, J.H., Bellwood, D.R., 1985. Interactions among herbivorous fishes on a coral reef: influence of spatial variation. Mar. Biol. 89, 221-234.

Chabanet, P., Ralambondrainy, H., Amanieu, M., Faure, G., Galzin, R., 1997. Relationships between coral reef substrata and fish. Coral Reefs 16, 93-102.

Denny, M.W., 1988. Biology and the mechanics of the waveswept environment. Princeton University Press, Princeton.

Dunson, W.A., Travis, J., 1991. The role of abiotic factors in community organization. Am. Nat. 138, 1067-1091.

Findley, J.S., Findley, M.T., 1985. A search for pattern in butterflyfish communities. Am. Nat. 126, 800-816.

Fowler, A.J., 1990. Spatial and temporal patterns of distribution and abundance of chaetodontid fishes at One tree Reef, southern GBR. Mar. Ecol. Prog. Ser. 64, 39-53.

Fulton, C.J., Bellwood, D.R., Wainwright, P.C., 2001. The relationship between swimming ability and habitat use in wrasses (Labridae). Mar. Biol. 139, 25-33.

Galzin, R., 1987. Structure of fish communities of French Polynesian coral reefs. I. Spatial scales. Mar. Ecol. Prog. Ser. 41, 129-136.

Galzin, R., Planes, S., Dufour, V., Salvat, B., 1994. Variation in diversity of coral reef fish between French Polynesian atolls. Coral Reefs 13, 175180.

Green, D.G., Bradbury, R.H., Reichelt, R.E., 1987. Patterns of predictability in coral reef community structure. Coral Reefs 6, 27-34.

Hindell, J.S., Jenkins, G.P., Keough, M.J., 2002. Variability in the numbers of post-settlement King George whiting (Sillaginidae: Sillaginodes punctata, Cuvier) in relation to predation, habitat complexity and artificial cage structure. J. Exp. Mar. Biol. Ecol. 268, 13-31.

Holbrook, S.J., Brooks, A.J., Schmitt, R.J., 2002. Predictability of fish assemblages on coral patch reefs. Mar. Freshwater Res. 53, 181-188.

Jones, G.P., 1991. Post-recruitment processes in the ecology of coral reef fish populations: a multifactorial perspective. In: Sale, P.F. (Ed.), The Ecology of Fishes on Coral Reefs. Academic Press, San Diego, pp. 237 294

Lecchini, D., Galzin, R., 2003. Influence of pelagic and benthic, biotic and abiotic, stochastic and deterministic processes on the dynamics of autorecruitment of coral reef fish: a review. Cybium in press.
Letourneur, Y., 1992. Dynamique des peuplements ichtyologiques des platiers récifaux de l'île de La Réunion. Univ Aix-Marseille II Thèse Océanographique biologique.

Levin, P.S., 1993. Habitat structure, conspecific presence and spatial variation on the recruitment of a temperate reef fish. Oecologia 94, 176-185.

McGehee, M.A., 1994. Correspondence between assemblages of coral reef fishes and gradients of water motion, depth, and substrate size off Puerto Rico. Mar. Ecol. Prog. Ser. 105, 243-255.

Munday, P.L., Jones, G.P., 1998. The ecological implications of small body size among coral-reef fishes. Oceanogr. Mar. Biol. Ann. Rev. 36, $373-$ 411.

Nishihira, M., 1987. Natural and human interference with the coral reef and coastal environments in Okinawa. Galaxea 6, 311-321.

Ohman, M.C., Rajasuriya, A., Olafsson, E., 1997. Reef fish assemblages in north western Sri Lanka: distribution patterns and influences of fishing practises. Environ. Biol. Fish. 49, 45-61.

Rakocinski, C.F., Baltz, D.M., Fleeger, J.W., 1992. Correspondence between environmental gradients and the community structure of marshedge fishes in a Louisiana estuary. Mar. Ecol. Prog. Ser. 80, 135-148.

Sale, P.F., 1980. The ecology of fish on coral reefs. Oceanogr. Mar. Biol. Ann. Rev. 18, 367-421.

Sano, M., 2001. Short term responses of fishes to macroalgal overgrowth on coral rubble on a degraded reef at Iriomote Island, Japan. Bull. Mar. Sci. $68,543-556$.

Sano, M., Shimizu, M., Nose, Y., 1987. Long-term effects of destruction of hermatypic corals by Acanthaster planci infestation on reef fish communities at Iriomote Island, Japan. Mar. Ecol. Prog. Ser. 37, 191-199.

Shima, J.S., 1999. Variability in relative importance of determinants of reef fish recruitment. Ecol. Lett. 2, 304-310.

Smith, C.L., Tyler, J.C., 1972. Space resource sharing in a coral reef fish community. In: Collette, B.B., Earle, S.A. (Eds.), Nat. Hist. Mus. Los Angeles County Sci. Bull., 14, pp. 125-170 Results of the Tektite Program: Ecology of Coral Reef Fishes.

Steele, M.A., Forrester, G.E., 2002. Early postsettlement predation on three reef fishes: effects on spatial patterns of recruitment. Ecology 83, 10761091.

Syms, C., Jones, G.P., 2000. Disturbances, habitat structure, and the dynamics of a coral-reef fish community. Ecology 81, 2714-2729.

ter Braak, C.J.F., 1986. Canonical correspondence analysis: a new eigenvector technique for multivariate direct gradient analysis. Ecology 67, 1167-1179.

Thresher, R.E., 1991. Geographic variability in the ecology of coral reef fishes: evidence, evolution, and possible interactions. In: Sale, P.F. (Ed.), The Ecology of Fishes on Coral Reefs. Academic Press, San Diego, pp. 401-436.

Veron, J.E.N., Minchin, P.R., 1992. Correlations between sea surface temperature, circulation patterns and the distribution of hermatypic corals. Cont. Shelf Res. 12, 835-857.

Wilks, S.S., 1932. Certain generalization in the analysis of variance. Biometrika 24, 1-471.

Williams, D.M.B., 1982. Patterns in the distribution of fish communities across the central Great Barrier Reef. Coral Reefs 1, 35-43.

Williams, D.M.B., 1991. Patterns and processes in the distribution of coral reef fishes. In: Sale, P.F. (Ed.), The Ecology of Fishes on Coral Reefs. Academic Press, San Diego, pp. 437-474. 